\title{
The synthesis of the bacteriocin sakacin $A$ is a temperature-sensitive process regulated by a pheromone peptide through a three- component regulatory system
}

\author{
Dzung B. Diep, ${ }^{1}$ Lars Axelsson, ${ }^{2}$ Camilla Grefsli ${ }^{1}$ and Ingolf F. Nes ${ }^{1}$
}

Author for correspondence: Dzung B. Diep. Tel: +47 649485 44. Fax: +47 64941465 . e-mail: dzung.diep@ikb.nlh.no

1 Laboratory for Microbial Gene Technology, Department of Biotechnological Sciences, Agricultural University of Norway, PO Box 5051, $\mathrm{N}-1432$ Ås, Norway

2 MATFORSK, Norwegian Food Research Institute Osloveien 1, N-1430 Ås, Norway

\begin{abstract}
Sakacin A is a bacteriocin produced by Lactobacillus sakei Lb706. The gene cluster (sap) encompasses a regulatory unit composed of three consecutive genes, orf4 and sapKR. sapKR encode a histidine protein kinase and a response regulator, while orf4 encodes the putative precursor of a 23-amino-acid cationic peptide (termed Sap-Ph). The authors show that Sap-Ph serves as a pheromone regulating bacteriocin production. Lb706 produced bacteriocin when the growth temperature was kept at 25 or $30^{\circ} \mathrm{C}$, but production was reduced or absent at higher temperatures $\left(33 \cdot 5-35^{\circ} \mathrm{C}\right)$. Production was restored by lowering the growth temperature to $30^{\circ} \mathrm{C}$, but at temperatures of $33-34{ }^{\circ} \mathrm{C}$ also by adding exogenous Sap-Ph to the growth medium. A knock-out mutation in orf4 abolished sakacin A production. Exogenously added Sap-Ph complemented this mutation, unambiguously showing the essential role of this peptide for bacteriocin production. Another sakacin A producer, Lactobacillus curvatus LTH1174, had a similar response to temperature and exogenously added Sap-Ph.
\end{abstract}

Keywords: three-component regulatory systems, temperature-sensitive bacteriocin production, peptide pheromones

\section{INTRODUCTION}

Many lactic acid bacteria secrete numerous small, cationic, heat-stable antimicrobial peptides ranging from 3 to $10 \mathrm{kDa}$ in size (Nes et al., 1996). Some of these compounds, commonly known as bacteriocins, are active against pathogenic and food-spoilage bacteria, and this has promoted much research on their potential as antimicrobials in food preservation.

To exploit their potential in various applications, these compounds need to be studied in detail. We have recently shown that bacteriocin production in both Lactobacillus plantarum C11 and Lactobacillus sakei LTH673 is an inducible process, triggered by small induction factor (IF) peptides, plantaricin $\mathrm{A}$ and the mature product of orf $Y$, respectively (the latter is hereafter referred to as Spp-Ph) (Diep et al., 1995, 1996; Eijsink et al., 1996; Brurberg et al., 1997). A similar regulatory mechanism has also been reported for nisin production, where nisin itself serves as the in-

Abbreviations: BU, bacteriocin unit; IF, induction factor; IU, induction unit; HPK, histidine protein kinase; RR, response regulator. duction factor (Kuipers et al., 1995). The genes ( $p \ln A$ and $\operatorname{orf} Y$ ) encoding plantaricin $\mathrm{A}$ and $\mathrm{Spp}-\mathrm{Ph}$ are both followed by genes encoding histidine protein kinases (HPKs) and response regulators (RRs), components of so-called signal-transducing pathways which are widely used in bacterial response to environmental changes (Stock et al., 1989). Such a three-component (IF, HPK and $\mathrm{RR}$ ) regulatory unit has also been noticed in the gene cluster responsible for sakacin A production (Axelsson \& Holck, 1995; Nes et al., 1996), i.e. orf4-sapKR, but the role of orf4 and its gene product has not been investigated.

In this communication we show that sakacin A production is a temperature-sensitive process, being reduced or totally abolished at elevated temperatures, and that the putative mature product of orf4 (termed Sap-Ph) possesses a regulatory role, triggering bacteriocin production as well as its own synthesis.

\section{METHODS}

Bacterial strains and growth conditions. Lactobacillus sakei Lb706 and L. curvatus LTH1174 (sakacin A producers; 
Schillinger \& Lücke, 1989; Tichaczek et al., 1992), L. sakei Lb790 (indicator strain and cloning host; Axelsson \& Holck, 1995) and transformed derivatives of these strains were, unless otherwise specified, grown on MRS (Difco) plates or in broth without agitation at $30^{\circ} \mathrm{C}$. To obtain nonproducing ( $\mathrm{Bac}^{-}$phenotype) cultures of Lb706 or LTH1174, inocula from a bacteriocin-conditioned culture $\left(\mathrm{Bac}^{+}\right.$phenotype) were diluted at least 1000 -fold in MRS broth and grown overnight $(16-24 \mathrm{~h})$ at $35^{\circ} \mathrm{C}$. The $\mathrm{Bac}^{-}$phenotype remained stable in the following subcultures when the cells were grown at above $33.5^{\circ} \mathrm{C}$ and $30^{\circ} \mathrm{C}$ for Lb706 and LTH1174, respectively. Transformants used in this study were grown in MRS medium containing erythromycin $\left(5 \mu \mathrm{g} \mathrm{ml}^{-1}\right)$ and chloramphenicol $\left(5 \mu \mathrm{g} \mathrm{ml}^{-1}\right)$.

Bacteriocin and induction assays. Bacteriocin production was quantified as previously described (Nissen-Meyer et al., 1993). $\mathrm{Sap}-\mathrm{Ph}$ (sakacin A induction factor) synthesis was assayed according to Diep et al. (1995), with the following modifications: (i) a fully grown overnight $\mathrm{Bac}^{-}$culture of LTH1174 (to be induced), was diluted 200-fold, and (ii) induction of bacteriocin production was tested by mixing $40 \mu \mathrm{l}$ of cell-free culture supernatant from each microtitre plate culture with $200 \mu \mathrm{l}$ of a diluted indicator culture (40-fold dilution of a fully grown overnight culture). Bacteriocin production was considered to have been induced when growth inhibition was at least $50 \%$. One induction unit (IU) was defined as the minimal amount of Sap-Ph that induced bacteriocin production in a microtitre plate culture as described above. Induction on plates was performed according to Diep et al. (1995), with the following modifications: (i) the supporting layer consisted of $12-15 \mathrm{ml}$ and each of the three soft-agar layers was of $3 \mathrm{ml}$, and (ii) the second layer contained approximately 20-50 c.f.u. Induction of the transformant L. sakei Lb790 containing the plasmids pSAK17B and pSAK20E in liquid cultures was performed as follows. Diluted cultures of the transformant were grown at $25^{\circ} \mathrm{C}$ until the $\mathrm{OD}_{600}$ was approximately $0 \cdot 1$ before appropriate amounts of synthetic Sap-Ph were added to induce bacteriocin production. Samples were collected at the indicated time-points and bacteriocin production in culture supernatants was assayed as described previously (NissenMeyer et al., 1993).

Mutagenesis of orf4. A mutation in orf4 was introduced by modifying the plasmid pSAK20A, encompassing a functional orf4-sapKRTE cassette (Axelsson \& Holck, 1995) by the PCR overlap extension technique (Horton \& Pease, 1991). PCRs were done as described by Axelsson \& Holck (1995). The derivative plasmid, pSAK20E, contained a frame-shift mutation in orf 4 by insertion of a $G$ in position 2578 and replacing $A$ at position 2583 with $C$, together creating a new EcoRI site (numbering according to the published sap sequence, GenBank accession number z46867; Axelsson \& Holck, 1995). pSAK20E was introduced into L. sakei Lb790, already containing the plasmid pSAK17B, as described previously (Axelsson \& Holck, 1995). Sakacin A production (seen as inhibition zones on plates) was tested qualitatively by overlaying spot colonies on plates containing no Sap-Ph or $10 \mathrm{ng}$ synthetic Sap-Ph ml-1 (see below) with an antibiotic-resistant derivative of the indicator strain Lb790 (Axelsson \& Holck, 1995), or monitored quantitatively in liquid cultures as described elsewhere.

RNA isolation and Northern analysis. $\mathrm{Bac}^{-}$and $\mathrm{Bac}^{+}$cultures of sakacin A producers were obtained as described above. Appropriate volumes of well-grown overnight cultures were inoculated into $100 \mathrm{ml}$ volumes of a prewarmed growth medium and cells were grown at the indicated temperatures for $1-2 \mathrm{~h}\left(\mathrm{OD}_{600}\right.$ approximately $\left.0 \cdot 1\right)$ before adding synthetic Sap-Ph at final concentration of $40 \mathrm{ng} \mathrm{ml} \mathrm{m}^{-1}$ to induce bacteriocin production. After induction for $4.5 \mathrm{~h}$ and $6.5 \mathrm{~h}$, samples were collected and RNA was isolated by the method of Igo \& Losick (1986). RNA concentration was determined spectrophotometrically at $260 \mathrm{~nm}$ and trace amounts of DNA in RNA samples were removed by DNase treatment. Three microlitres of RNA at a concentration of either $0 \cdot 1$ or $1 \mu \mathrm{g} \mu \mathrm{l}^{-1}$ was spotted directly on a cellulose membrane (Gene Screen Plus; Dupont), which was subsequently dried for $2 \mathrm{~h}$ at room temperature for fixation. Hybridization was performed as described by Lillehaug et al. (1991), using a DNA fragment as probe specific to the genes saiA and sapA (see Fig. 2). The DNA fragment was obtained by PCR using primers SakAP1 and SakAP2 (see below) and the correct PCR product was purified by gel electrophoresis before random ${ }^{32} \mathrm{P}$ labelling according to the manufacturer's recommendations (Random Primed DNA Labelling Kit; Boehringer Mannheim). The primers SakAP1 and SakAP2 have coordinates 664-682 and 1065-1047, respectively, with regard to the published sequence (accession number z46867).

\section{RESULTS}

\section{Temperature-sensitive bacteriocin production}

In liquid cultures, L. sake $i$ Lb706 produced high amounts of bacteriocin $\left(250-500 \mathrm{BU} \mathrm{ml}^{-1}\right.$ in the overnight cultures) when the growth temperature was kept at 25 or $30{ }^{\circ} \mathrm{C}$. Production was reduced (less than $80 \mathrm{BU} \mathrm{ml}^{-1}$ ) at $33.5^{\circ} \mathrm{C}$ and disappeared at $34.5^{\circ} \mathrm{C}$ or higher. Once a culture had lost the ability to produce bacteriocin $\left(\mathrm{Bac}^{-}\right.$ phenotype), subcultures from it continued to be $\mathrm{Bac}^{-}$ when grown at an elevated temperature (i.e. $33.5^{\circ} \mathrm{C}$ or higher). Only when the temperature was lowered to a 'permissive' level, 25 or $30^{\circ} \mathrm{C}$, was normal production restored. On plates (multi-layer plate assay), high bacteriocin production occurred at $30^{\circ} \mathrm{C}$, seen as clear and uniform inhibition zones surrounding the colonies (Fig. 1a). Similar results were obtained at $25^{\circ} \mathrm{C}$ (not shown). At $33{ }^{\circ} \mathrm{C}$ the inhibition zones surrounding the colonies were less uniform and smaller, and some colonies even appeared without inhibition zones (Fig. 1b). At $35^{\circ} \mathrm{C}$ no clear inhibition zones were seen (Fig. 1c). $\mathrm{Bac}^{-}$cells retained this phenotype when grown on plates at 33 or $35^{\circ} \mathrm{C}$ but regained the ability to produce bacteriocin when grown at permissive temperatures $(25$ to $30^{\circ} \mathrm{C}$ ) (not shown). These results indicated that bacteriocin production in Lb706 was a temperaturesensitive process.

L. curvatus LTH1174 produces a bacteriocin originally termed curvacin A (Tichaczek et al., 1992). Further characterization has revealed that curvacin $\mathrm{A}$ is identical to sakacin A. The genetic systems also appear identical, except that Lb706 contains an IS-element in its bacteriocin locus while LTH1174 does not (Axelsson \& Holck, 1995) (see Fig. 2a). In similar experiments as described above, bacteriocin production in LTH1174 was also shown to be a temperature-sensitive process, but with following differences as compared to Lb706. Overnight $\mathrm{Bac}^{+}$cultures contained about 1000$2000 \mathrm{BU} \mathrm{m}{ }^{-1}$, $500 \mathrm{BU} \mathrm{ml}^{-1}$ and $100 \mathrm{BU} \mathrm{ml}^{-1}$ when grown at $25^{\circ} \mathrm{C}, 30^{\circ} \mathrm{C}$ and $33.5^{\circ} \mathrm{C}$, respectively. Nor- 


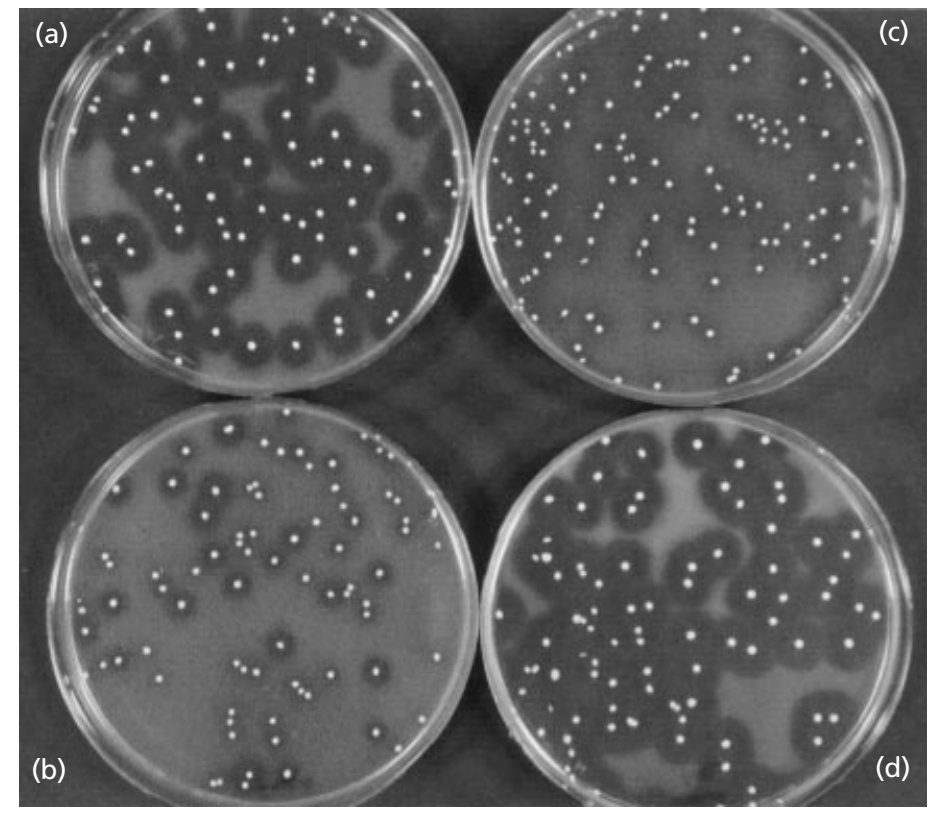

Fig. 1. Sakacin A production in Lb706 is temperature sensitive and inducible. Temperature sensitivity and inducibility of bacteriocin production were examined using the multi-layered assay described in Methods. The producer $L$. sakei 706 was first grown overnight $(16-24 \mathrm{~h})$ on plates at $30^{\circ} \mathrm{C}$ (a), $33^{\circ} \mathrm{C}$ (b), $35^{\circ} \mathrm{C}$ (c) and $33^{\circ} \mathrm{C}(\mathrm{d})$, and then the plates were overlaid with the indicator strain Lb790. Lb706 cells on plates (a), (b) and (c) were all derived from a $\mathrm{Bac}^{+}-$ conditioned culture whereas Lb706 cells on plate (d) were from a $\mathrm{Bac}^{-}$-conditioned culture. In plate (d), Sap-Ph was added in the induction layer at $40 \mathrm{ng} \mathrm{m}^{-1}$ to induce bacteriocin production.

(a)

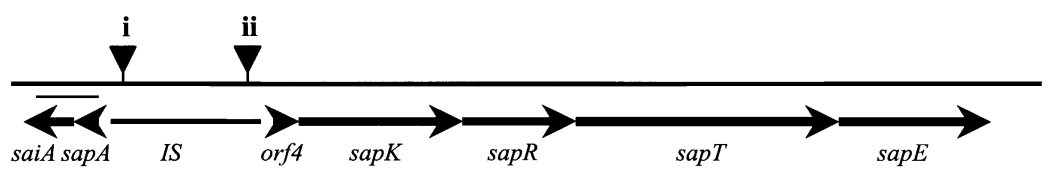

(b) Orf4: MKLNYIEKKQLTNKQLKLIIGG $\stackrel{\downarrow}{\text { TNRNYGKPNKDIGTCIWSGFRHC }}$

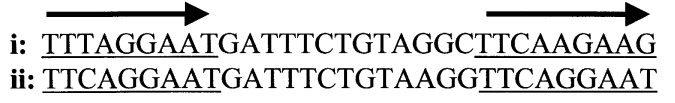

Fig. 2. Genetic organization of the sap locus (a). The genes sapKRTE code for an HPK, an RR, an ABC-transporter and its cognate accessory protein, respectively; the gene pair sapA and saiA code for the bacteriocin precursor and the immunity protein. orf4 encodes the Sap-Ph precursor, which contains a double-glycine leader (b). Triangles in (a) indicate promoterproximal regulatory-like direct repeats whose sequences are shown in (c); the arrow in (b) indicates the putative proteolytic cleavage site that results in formation of the mature peptide (underlined). The DNA fragment used as probe to analyse sapAsaiA transcript is indicated by the thin line in (a).

mally, there was no production at higher growth temperatures $\left(34 \cdot 5-37^{\circ} \mathrm{C}\right)$. Unlike that of Lb706, a Bac ${ }^{-}$ culture of LTH1174 did not regain the $\mathrm{Bac}^{+}$phenotype when the growth temperature was lowered to $30^{\circ} \mathrm{C}$. Normal bacteriocin production was re-established only when the temperature was further lowered to $25^{\circ} \mathrm{C}$.

\section{Sap-Ph induces bacteriocin production}

The sap locus responsible for sakacin A production in Lb706 encompasses a three-component regulatory unit (orf4-sapKR) (Axelsson \& Holck, 1995) similar to the plantaricin A and sakacin P systems (Nes et al., 1996). orf4 encodes a peptide containing a so-called doubleglycine leader (Axelsson \& Holck, 1995) and could give rise to a mature 23 -amino-acid peptide (hence referred to as Sap-Ph), analogous to plantaricin A and Spp-Ph (Nes et al., 1996), while sapKR encode an HPK and an RR, respectively (see Fig. 2a). The amino acid sequence of Sap-Ph is shown in Fig. 2(b). The instability of sakacin A production, observed at the elevated temperatures, was thought to be due to an intrinsic regulation involving the three-component regulatory unit. To test this hypothesis, synthetic Sap-Ph was obtained. Using the multilayer induction plate assay, we found that addition of $\mathrm{Sap}-\mathrm{Ph}$ in the third layer $\left(40 \mathrm{ng} \mathrm{ml}^{-1}\right)$ induced bacteriocin production in both Lb706 (at $33.5^{\circ} \mathrm{C}$ ) (Fig. 1d) and LTH1174 (at $30^{\circ} \mathrm{C}$ ) (data not shown). Synthetic plantaricin A and Spp-Ph, and protease-treated $\mathrm{Sap}-\mathrm{Ph}$, did not induce bacteriocin production (data not shown), demonstrating that the induction was Sap-Ph-specific. 
Table 1. Induction and bacteriocin activity in culture supernatants from cultures grown at various temperatures and with or without induction

\begin{tabular}{|c|c|c|c|c|c|c|c|c|}
\hline \multirow{4}{*}{$\begin{array}{r}\text { From temp. }{ }^{*}: \\
\text { To temp. }{ }^{*}: \\
\text { Sap-Ph }+:\end{array}$} & \multicolumn{6}{|c|}{ Lb706 } & \multicolumn{2}{|c|}{ LTH1147 } \\
\hline & 30 & 35 & 35 & 35 & 35 & 35 & 35 & 35 \\
\hline & 30 & 30 & $33 \cdot 5$ & $33 \cdot 5$ & $34 \cdot 5$ & $34 \cdot 5$ & 30 & 30 \\
\hline & - & - & - & + & - & + & - & + \\
\hline \multicolumn{9}{|c|}{ Induction $\left(10^{3} \times \mathrm{IU} \mathrm{ml}^{-1}\right) \neq$} \\
\hline $0 \mathrm{~h}$ & $0 \cdot 5$ & 0 & 0 & ND & 0 & ND & 0 & 20 \\
\hline $2 \mathrm{~h}$ & $1-1 \cdot 5$ & 0 & 0 & $\mathrm{ND}$ & 0 & ND & 0 & 20 \\
\hline $4 \mathrm{~h}$ & 5 & 0 & 0 & ND & 0 & ND & 0 & 20 \\
\hline $6 \mathrm{~h}$ & $20-25$ & 10 & 0 & ND & 0 & ND & 0 & $20-25$ \\
\hline $8 \mathrm{~h}$ & $20-25$ & $20-25$ & 0 & $\mathrm{ND}$ & 0 & ND & 0 & $65-70$ \\
\hline $10 \mathrm{~h}$ & $20-25$ & $20-25$ & 0 & $\mathrm{ND}$ & 0 & ND & 0 & $65-70$ \\
\hline \multicolumn{9}{|c|}{ Bacteriocin $\left(\mathrm{BU} \mathrm{m} \mathrm{l}^{-1}\right)$} \\
\hline $2 \mathrm{~h}$ & 0 & 0 & 0 & 0 & 0 & 0 & 0 & 0 \\
\hline $4 \mathrm{~h}$ & 20 & 0 & 0 & 0 & 0 & 0 & 0 & 0 \\
\hline $6 \mathrm{~h}$ & 80 & 20 & 0 & 20 & 0 & 0 & 0 & 40 \\
\hline $8 \mathrm{~h}$ & 160 & 80 & 0 & 40 & 0 & 20 & 0 & 80 \\
\hline $10 \mathrm{~h}$ & 320 & 160 & 0 & 160 & 0 & 40 & 0 & 80 \\
\hline
\end{tabular}

*Numbers in the upper row ('From temp.') indicate the temperatures in the overnight cultures used as sources for inocula; numbers in the lower row ('To temp.') indicate the temperatures applied to grow the cells in this study.

† Minus and plus signs indicate without or with addition of synthetic Sap-Ph $\left(40 \mathrm{ng} \mathrm{ml}^{-1}\right)$ to induce bacteriocin production.

$\ddagger$ ND, Not determined.

\section{Genetic evidence for the role of orf4 and Sap-Ph}

The sap genes can be divided into two operons, i.e. sapAsaiA and orf4-sapKRTE, respectively (see Fig. 2a). These two operons complement each other when present on two separate plasmids (pSAK20A containing orf4sapKRTE and pSAK17B containing sapAsaiA) in the same strain, resulting in sakacin A production and immunity (Axelsson \& Holck, 1995). A derivative of pSAK20A, pSAK20E, differing only in an introduced frame-shift mutation in orf4, was constructed. The resulting recombinant L. sakei Lb790 containing plasmids pSAK17B and pSAK20E was sakacin A negative in a standard agar-overlay assay at $25^{\circ} \mathrm{C}$ (data not shown). However, adding $10 \mathrm{ng} \mathrm{ml}^{-1}$ of Sap-Ph in the plates resulted in sakacin A producing colonies (data not shown). orf4 was thus essential for sakacin A production and exogenously added Sap- $\mathrm{Ph}$ complemented a mutation in orf4.

\section{Coordinated production of sakacin A and Sap-Ph}

The synthesis of Sap-Ph in strain Lb706 was further examined with regard to its production in relation to sakacin A production. As shown in Table 1, only cellfree supernatants derived from $\mathrm{Bac}^{+}$-conditioned cultures (grown at $30^{\circ} \mathrm{C}$ ) were capable of inducing bacteriocin production; those derived from $\mathrm{Bac}^{-}$-conditioned cultures (grown at $33.5^{\circ} \mathrm{C}$ or higher) were not. The inducer was found to be heat-stable: its activity in

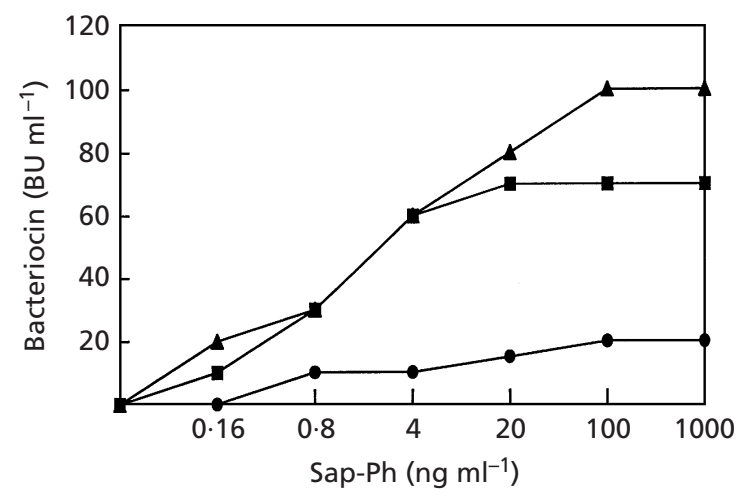

Fig. 3. Sap-Ph induces bacteriocin production in the recombinant Lb790 containing the plasmids pSAK17B and pSAK20E. The derivative plasmid, pSAK20E, contained a frameshift mutation in orf4, which encodes the precursor of Sap$\mathrm{Ph}$; see Methods. The cultures were induced with the indicated concentrations of Sap-Ph, and bacteriocin production in culture supernatants was monitored at $4(\mathbf{O}), 6(\boldsymbol{\square})$ and $8(\boldsymbol{\Delta}) \mathrm{h}$ after addition of the inducer.

culture supernatants resisted boiling for at least $15 \mathrm{~min}$ (data not shown). The induction efficiency was also examined at the elevated temperatures. Some bacteriocin activity was observed at the elevated temperatures when cells were grown in the presence of the inducer $\left(40 \mathrm{ng} \mathrm{ml}^{-1}\right)$; however, the production appeared to be less at the highest temperature $\left(34.5^{\circ} \mathrm{C}\right)$ 


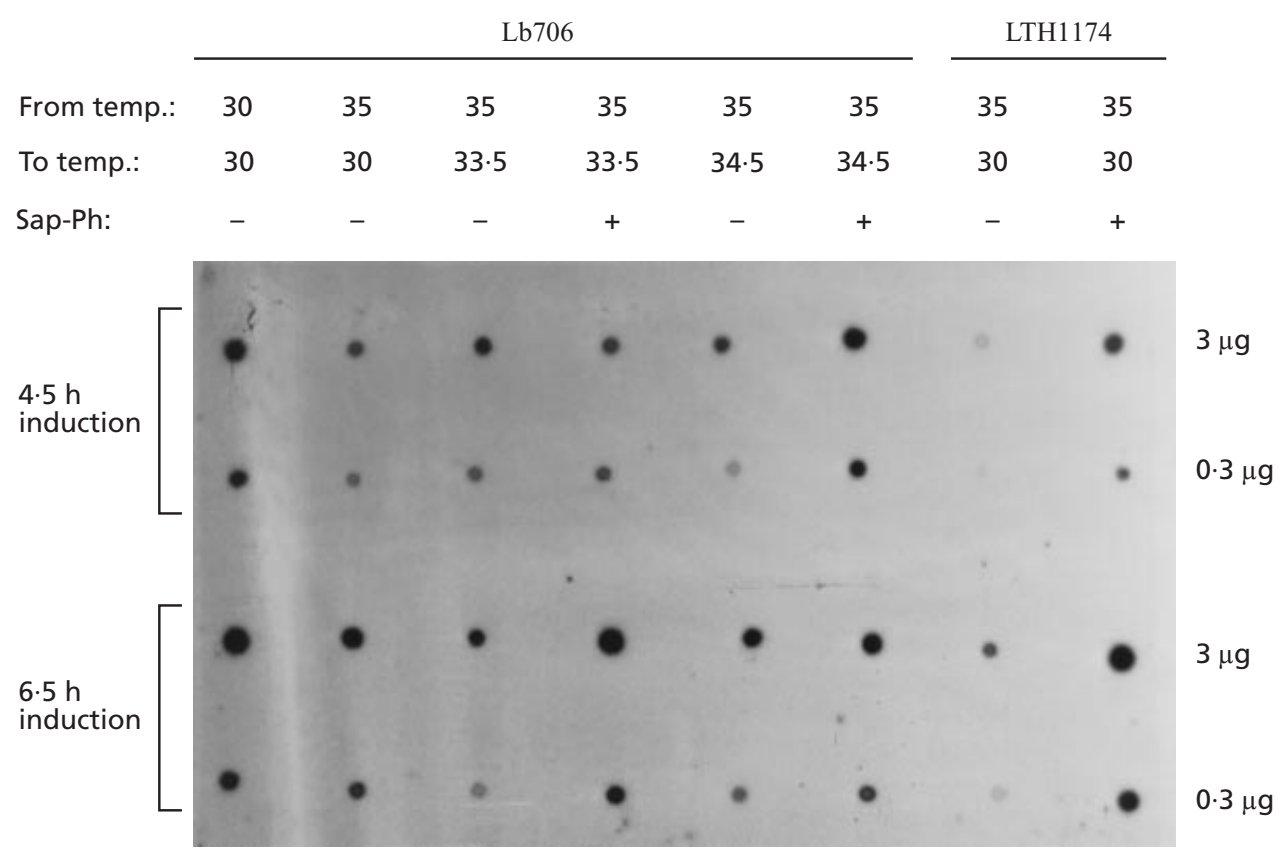

Fig. 4. Transcription of the bacteriocin operon is a temperature-sensitive process and is activated by Sap-Ph. See Methods for details of the experiment. Cell inocula were derived from cultures ('From temp.') which had been grown at $30{ }^{\circ} \mathrm{C}$ (to obtain $\mathrm{Bac}^{+}$cells for Lb706) or $35^{\circ} \mathrm{C}$ (to obtain Bac cells for both Lb706 and LTH1174), and the diluted cultures were then incubated at indicated temperatures ('To temp.') for cell growth. Cell samples were collected at $4.5 \mathrm{~h}$ and $6.5 \mathrm{~h}$ after addition of Sap-Ph for RNA isolation; plus and minus signs indicate with and without addition of Sap-Ph, respectively. The cellulose membrane was spotted with $0.3 \mu \mathrm{g}$ and $3 \mu \mathrm{g}$ of each RNA sample. The location of the DNA fragment used as a probe specific to sapAsaiA is shown in Fig. 2(a).

than at the lower temperatures $\left(30-33 \cdot 5^{\circ} \mathrm{C}\right)$, see Table 1. Furthermore, when using the recombinant strain $L$. sake $i$ Lb790 that contained both the plasmids pSAK17B and pSAK20E, the amounts of sakacin A produced seemed to be somewhat correlated with that of Sap-Ph added to the cultures, e.g. higher bacteriocin production was found in cultures with high amounts of Sap-Ph added (Fig. 3).

To examine transcription of the bacteriocin operon under various growth conditions, Northern analysis was performed using a probe specific to both the bacteriocin structural gene (sapA) and its immunity gene (saiA), on RNA isolated from cultures grown at various growth temperatures and with or without addition of Sap-Ph. As shown in Fig. 4, poor signal intensity was observed for both production strains when RNA was derived from cultures which had been grown under nonproducing conditions, i.e. at elevated temperatures and without addition of the inducer. However, the signal intensity was clearly increased when RNA isolated from $\mathrm{Bac}^{+}$-conditioned cultures was used. These results indicated that the bacteriocin production is regulated at the transcriptional level.

\section{DISCUSSION}

We have in this report shown that sakacin A production in L. sakei Lb706 and L. curvatus LTH1174 is regulated by a three-component regulatory unit, and that the production is a temperature-sensitive process, a phenomenon which has not been described before in related systems. Furthermore, we have been able to identify the cause of production instability at elevated temperatures, namely a reduced synthesis of the pheromone peptide Sap-Ph, a component of the associated autoregulatory unit. The involvement of the pheromone peptide was also evidenced by knock-out analysis of its gene, orf4. The mutant with a frame-shift mutation in this gene did not produce any bacteriocin at all unless the inducer was exogenously added to the growth medium.

The sakacin A producers L. sakei Lb706 and L. curvatus LTH1174 contain an almost identical genetic background for bacteriocin production and regulation (Tichaczek et al., 1992; Axelsson \& Holck, 1995). It is therefore not very surprising that their bacteriocin production was regulated in a somewhat similar manner, i.e. both being temperature-sensitive and regulated by the same pheromone peptide. However, they also displayed some small differences in their response to various cardinal temperatures. The molecular basis of these dissimilarities is still unknown. We have noted previously that the operator regions of both the sap operons have some features in common; each operon is preceded by a pair of conserved direct repeats with a defined spacer length resembling regulatory elements see Fig. 2(c) (Axelsson \& Holck, 1995 ; Diep et al., 1996). Such regulatory-like elements are also present in the 
operator regions associated with the $p l n$ and $s p p$ systems and we have recently demonstrated that these direct repeats are intrinsic DNA regulatory elements on which the cognate response regulators bind and regulate gene transcription (Risøen et al., 1998). Thus it is reasonable to assume that the two sap operons are regulated in a similar manner, i.e. the product of $s a p R$, which encodes a response regulator, binds on the promoter-proximal repeats and activates transcription of both the sap operons. This model is also supported by the fact that synthesis of Sap-Ph was found to be coordinated with that of the bacteriocin, i.e. the inducer was found only in the $\mathrm{Bac}^{+}$-conditioned culture supernatants but not in the $\mathrm{Bac}^{-}$-conditioned culture supernatants (Table 1).

The presence of a regulatory system for sakacin A production has been somewhat of a puzzle, since production always has appeared to be constitutive (Holck et al., 1992; Axelsson \& Holck, 1995). In this report, we have shown that the system is necessary for production and that Sap-Ph is needed for induction. Such a three-component regulatory system involving a pheromone peptide and a cognate signal-transducing network not only seems to be frequently used in the regulation of bacteriocin production from different species (Kleerebezem et al., 1997), but has also been found to play key roles in other biological pathways. Examples are the com and $a g r$ systems that control competence development in streptococci and the expression of virulence proteins during stationary growth phase in Staphylococcus aureus, respectively (Novick et al., 1995; Pestova et al., 1996). For the sakacin A system, however, the question remains whether the temperature 'switch' has some function in vivo, and/or if the system works as a quorum-sensing device as suggested for the nisin system (Kuipers et al., 1995; Kleerebezem et al., 1997).

\section{ACKNOWLEDGEMENTS}

This work was in part supported by a grant from the Norwegian Research Council (no 104988/110).

\section{REFERENCES}

Axelsson, L. \& Holck, A. (1995). The genes involved in production of and immunity to sakacin A, a bacteriocin from Lactobacillus sakei Lb706. J Bacteriol 177, 2125-2137.

Brurberg, M. B., Nes, I. F. \& Eijsink, V. G. H. (1997). Pheromoneinduced production of antimicrobial peptides in Lactobacillus. Mol Microbiol 26, 347-360.

Diep, D. B., Håvarstein, L. S. \& Nes, I. F. (1995). A bacteriocin-like peptide induces bacteriocin synthesis in Lactobacillus plantarum C11. Mol Microbiol 18, 631-639.

Diep, D. B., Håvarstein, L. S. \& Nes, I. F. (1996). Characterization of the locus responsible for the bacteriocin production in Lactobacillus plantarum C11. J Bacteriol 178, 4472-4483.
Eijsink, V. G. H., Brurberg, M. B., Middelhoven, P. H. \& Nes, I. F. (1996). Induction of bacteriocin production in Lactobacillus sakei by a secreted peptide. J Bacteriol 178, 2232-2237.

Holck, A., Axelsson, L., Birkeland, S.-E., Aukrust, T. \& Blom, H. (1992). Purification and amino acid sequence of sakacin $A$, a bacteriocin from Lactobacillus sakei Lb706. J Gen Microbiol 138, 2715-2720.

Horton, R. M. \& Pease, L. R. (1991). Recombination and mutagenesis of DNA sequences using PCR. In Directed Mutagenesis: a Practical Approach, pp. 217-247. Edited by M. J. McPherson. Oxford, UK: IRL Press.

Igo, M. M. \& Losick, R. (1986). Regulation of a promoter that is utilized by minor forms of RNA polymerase holoenzyme in Bacillus subtilis. J Mol Biol 191, 615-624.

Kleerebezem, M., Quadri, L. E. N., Kuipers, O. P. \& de Vos, W. M. (1997). Quorum sensing by peptide pheromones and twocomponent signal-transduction systems in Gram-positive bacteria. Mol Microbiol 24, 895-904.

Kuipers, O. P., Beerthuyzen, M. M., de Ruyter, P. G. G. A., Luesink, E. J. \& de Vos, W. M. (1995). Autoregulation of nisin biosynthesis in Lactococcus lactis by signal transduction. J Biol Chem 270, 27299-27304.

Lillehaug, D., Lindqvist, B. \& Birkeland, N. K. (1991). Characterization of phiLC3, a Lactococcus lactis subsp. cremoris temperature bacteriophage with cohesive single-stranded DNA ends. Appl Environ Microbiol 57, 3206-3211.

Nes, I. F., Diep, D. B., Håvarstein, L. S., Brurberg, M. B., Eijsink, V. \& Holo, H. (1996). Biosynthesis of bacteriocins in lactic acid bacteria. Antonie Leeuwenhoek 70, 113-128.

Nissen-Meyer, J., Larsen, A. G., Sletten, K., Daeschel, M. \& Nes, I. F. (1993). Purification and characterization of plantaricin A, a Lactobacillus plantarum bacteriocin whose activity depends on the action of two peptides. J Gen Microbiol 139, 1973-1978.

Novick, R. P., Projan, S. J., Kornblum, J., Ross, H. F., Ji, G., Kreiswirth, B., Vandenesch, F. \& Moghazeh, S. (1995). The agr P2 operon: an autocatalytic sensory transduction system in Staphylococcus aureus. Mol Gen Genet 248, 446-458.

Pestova, E. V., Håvarstein, L. S. \& Morrison, D. A. (1996). Regulation of competence for genetic transformation in Streptococcus pneumoniae by an auto-induced peptide pheromone and a twocomponent regulatory system. Mol Microbiol 21, 853-862.

Risøen, P. A., Håvarstein, L. S., Diep, D. B. \& Nes, I. F. (1998). Identification of the DNA-binding sites for two response regulators involved in control of bacteriocin synthesis in Lactobacillus plantarum c11. Mol Gen Genet 259, 224-232.

Schillinger, U. \& Lücke, F.-K. (1989). Antibacterial activity of Lactobacillus sakei isolated from meat. Appl Environ Microbiol 55, 1901-1906.

Stock, J. B., Ninfa, A. J. \& Stock, A. M. (1989). Protein phosphorylation and regulation of adaptive responses in bacteria. Microbiol Rev 53, 450-490.

Tichaczek, P. S., Nissen-Meyer, J., Nes, I. F., Vogel, R. F. \& Hammes, W. P. (1992). Characterization of the bacteriocins curvacin A from Lactobacillus curvatus LTH1174 and sakacin P from L. sakei LTH673. Syst Appl Microbiol 15, 460-468.

Received 31 December 1999; revised 19 April 2000; accepted 24 May 2000. 